\title{
Welfare's forgotten past: a socio-legal history of the poor law
}

\author{
by Lorie Charlesworth
}

The author presented this seminar at the IALS on February 5 to launch the publication of her book of the same title.

I t may seem rather obvious to state that: "Poor law was law"; nevertheless, this basic legal truth has slipped from the consciousness of those researching and publishing nationally and internationally on the history of welfare in England and Wales. As a result of this slippage, the legal underpinnings of that system of relieving poverty have been marginalised, misunderstood, denied and forgotten. Although most current welfare textbooks make reference to welfare's poor law past, few acknowledge that England and Wales (Scotland and Ireland have a different welfare history) possess the oldest continuous surviving legal system of welfare relief in Europe; a 400-year-old common law (later public law) locally funded and administered system of relieving poverty. This positive cultural norm deserves celebrating. In addition, the weight of such a socio-legal history ensures that many echoes of that past resonate in modern welfare law. In particular, these comprise elements of localism and an acceptance, albeit sometimes grudgingly by both governments and citizens, that the poor will be relieved of poverty. These aspects predate the modern British Welfare State by hundreds of years.

One consequence of this neglect, the "forgotten" of the title, is that many scholars are unaware of the extent of those legal foundations that ensured poor law was not simply local custom developing over time. Rather, those legal aspects of poor law discussed in this book became entrenched within society creating long term, if often unrecognised, legal norms. The most significant of these, discussed more fully throughout the book, is the largely forgotten, often denied and hence underestimated legal right to relief. Such is the level of "forgetting" that this book's fundamental assertion, that poor law encompasses a legal right to relief, remains controversial as counter to current orthodoxy amongst historians. In consequence, their denial of this right has been followed in academic legal texts. However, in chapter 3 this book sets out detailed legal "proofs", supported by archival and other research, to reveal those legal obligations, rights
On one level, this book is a legal opinion that the "law of settlement and removal" is at the heart of the poor law, that its doctrines encompass rights, duties and obligations by all citizens of England and Wales and that the settled poor possessed a legal right to relief in and from their place of settlement. This conclusion emerges from research conducted in two dimensions. The first is concerned with small stories, micro-histories of ordinary people and how they experienced law. Additionally, the work reconstructs law's pervasiveness, its theoretical and doctrinal nature, development and influences. Such an approach, involving often-contradictory methodologies destabilises an orthodox approach to legal history, hence the title of this work is a socio-legal rather than a social or legal history.

The second (parallel) dimension of the book constitutes a revisionist reconstruction of current orthodox interpretations of poor law's history, particularly in chapter 4 , in order to [re]place a legal right correctly within its historical framework. In addition, other chapters of the work trace those contemporary juristic and contingent elements that have contributed to poor law historians adopting an incorrect legal stance. Further chapters reconstruct poor law's legal past from a number of perspectives; that of reformers, protestors, the excluded, those who administer relief and those who receive it.

In adopting a socio-legal approach, this work demonstrates that poor law histories and empirical research, viewed through the lens of law, fully substantiate the existence of a right to relief. This remains so even where historians themselves believe that they are revealing cultural or political patterns of social negotiation and not a legal framework. Finally, it is important to underline that despite much resonance and some survivals, poor law is not the same as modern welfare law. That consists of public administrative law operating within a central bureaucratic framework funded by a system of national taxation and directed by whichever government is currently in power. 
On the contrary, as is explored within the work, until 1865 and in some aspects beyond, "poor law" constitutes an over-arching common law legal "system" that also encompasses local autonomy, local financial obligations, duties and responsibilities with ad hoc relief patterns. Within this "system" the localities manifest individual characteristics according to amongst other factors, local financial, social and property-owning circumstances.

However, all local parishes share two common elements: first, that the Justices at Sessions annually ratify and thus supervise those poor law activities; and second, that all relief decisions are made in the context of a legal framework comprising the common law of settlement and removal, the right to relief, other legal "rules" and established legal processes. This is not that "legal" model of exclusion, control and "undeserving" that is increasingly popular as an academic reading of poor law; rather it reveals a complex, nuanced and sophisticated system based upon rights.

This is, of course, not the final word; in challenging conventional non-legal assumptions about poor law the writer wishes to re-open a closed discussion. It is timely to refocus both lawyers and historians' intellectual attention upon those rights-based elements that socio-legal research reveals as a fundamental element of welfare's past. For their part, historians have concentrated on discovering the nature, operation and changing social impact of the poor law from those legal records held in archives rather than undertaking legal reconstructions. Their "law" discussions are largely constructed around a narrative account of statutes sourced from the work of other historians, often traceable to the negative perceptions found in the Webbs' poor law histories, not legal texts. The overall effect explains why the legal history of poor law often repels historians; but it is considerably more than: "one damn statute after another."

In spite of these comments, this absence of legal knowledge does not represent academic failure. It is rather a manifestation of a lack of "law mindedness"; no different from that "history blindness" afflicting many legal academics. This lack however, does partially explain why so many historians deny the existence of a legal right to relief. Of course this writer acknowledges that historians produce detailed and scholarly analyses, derived from study undertaken within an abundance of surviving poor law archival materials. Paradoxically, the explanation for the continued survival of those records is found in their legal nature, that they record poor law legal duties, rights and responsibilities. In consequence, both the existence and survival of these archives are evidence of the power and significance of that overarching framework of substantive legal rules surrounding the relief of poverty.

More specifically, at base all these records owe their origins to three legal imperatives contained within poor law. Firstly, every parish and vestry in England and Wales had a legal duty to raise a rate to maintain its poor under the authority of the terms of an Act for the Better Relief of the Poor 1601. The second, a complex common law presumption underpinning that Act and so understood and expressed in all subsequent case law and explored within the book, was that every person born in England and Wales possessed a settlement somewhere. In consequence, in that place a settled person was legally entitled to relief if destitute. This precise geographical place could only be established via legal interpretation of the "rules" and precedents contained within the law of settlement and removal. Some aspects of that settlement entitlement were first expressed in statute in 1662. However, the settlement entitlement has an earlier common law existence explored in chapter 3.

The third imperative was that a poor person could only be removed to their settlement parish by operation of formal legal process and if they appeared likely to (before 1795) or actually sought poor relief. Thus, it was not social altruism or "custom" that motivated the provision of poor relief, rather long-standing legal "rules." In short, underpinning all poor law documents recording the activities of officials administering the system, setting and collecting a poor rate, recording details of those relieved, indeed the very system of welfare itself, is the legal right of the settled poor to relief when destitute.

From a lawyer's perspective it appears perverse that this legal "truth", constantly attested to in case law and stated within contemporary legal texts and justices' manuals, is rejected by historians and thus "lost" to legal and other academics who follow their lead. The book aims to undermine this incorrect yet persistent stance. One possible explanation for that law-blindness (others are explored within the book) may be found in the influence of those reforms implemented via the terms of the Poor Law Amendment Act 1834. This initiated the new poor law, born of Benthamite positivism and Whiggish reformist theories of political economy. The birth of this baby heralded the arrival of the hated new poor law with its national system of prison-like workhouses. Although settlement law remained after 1834, as did the right to relief, the manner of that relief became bureaucratised according to the terms of the Act and was only to be available in a Union workhouse. Consequentially, the poor are characterised as a problem to be contained, controlled and stigmatised out of their state of poverty. This direction cast the die for English welfare, pathologising poverty and may have served to further influence historians' rejection of the existence of legal rights possessed by the poor.

What is more; so influential and pervasive are the negative social effects of those reforms that a cultural stigma surrounding poverty persists today despite the establishment of the Welfare State in 1948. The book's various chapters discuss how elements of that "new poor law" mind-set personified and promoted negative assumptions and presumptions concerning the poor and the role of welfare. Such persistent deformations, 
dichotomising welfare values, represent a problem that continues to profoundly affect the modern application of welfare law, thus forming part of the inspiration for this book. For this reason, the work is not intended as a study of an historical curiosity but rather an exploration of when, how and why such negativity arose and how it continues to hold sway despite the "abolition" of the last of those hated poor law remnants by the Beveridge reforms. In consequence of that past, the horrors of the post 1834 poor law system are well known, although not those positive rights-based aspects whose origins lie much earlier.

This book suggests that there are additional factors that continue to influence current mis-understanding of welfare's legal past. The first is the persistence of that negative ideology prevalent within the Webbs' poor law histories prompted by their political agenda that downplays any positive aspects of the poor law. Their works remain influential and although subsequently criticised remain part of poor law orthodoxy for many scholars, both in Britain and elsewhere. The second is that the "abolition" of poor law in 1948, ostensibly swept away by the new broom of Beveridge, left a message that nothing in welfare's past had value for society and the poor. The third is a result of that legal abolition; namely that poor law as a legal subject disappeared from legal practice and legal memory. All these factors compound the "forgetting" of the significance of that rights basis to the poor law.

That neglected, lost aspect of poor law's history is the focal point of the book. This "forgetting" or minimising of a legal, enforceable right to relief derived from, and located within the possession of a legal settlement, has led historians seriously to underestimate its significance within the lived experience of the poor. As a result, a "history of poverty" has developed which does not take into account the power and legal formality of that right; or at best, seriously underestimates its significance for the poor, local ratepayers and those who administered the system. This book aims to redress that imbalance, combining social and legal history. In consequence, it is one reply to that rhetorical question posed by Richard Evans: "what has law to say to history?" This writer suggests that for poor law studies at least, viewing welfare's past through the lens of law opens other windows to that past to disclose an alternative landscape. An examination of its topography reveals that poor law was law, that a legal framework informs all poor law activity and that there was a common law right to relief. Such a right enforceable in person, as we shall see, is precious indeed and deserves to be remembered and celebrated. Its existence reminds us that human rights are not a creation of modernity and that the common law has protected personal rights throughout its long history.

The emergence of common law poor law may be technically dated from the Act of 1601, which constitutes the legal authority for all poor relief in England and Wales until 1948 and is so expressed in all case law. That Act may be read partially as innovative but it also embodies those legal presumptions underpinning those poor law statutes enacted during the previous seventy post-Reformation years, a topic more fully explored in the book. There are three points of legal interest; the first is that the obligation by each parish to relieve is "understood" as in earlier statutes but is not articulated; it is the financial and administrative issues that are detailed. The second, who is to be relieved, is also "understood" and partly set out in the earlier statutes; that is a person born in the parish, or who has resided there for three years, this constitutes the settlement entitlement. Finally, in its terms this Act clones the ecclesiastical parish into a civil parish, whose residents are instructed to annually appoint unpaid parish officials to administer the poor law; marking the birth of English local government. Thus two discrete legal bodies, one secular one ecclesiastical each with their own specific functions and responsibilities, co-exist in one parish, comprising the same individuals in the same geographical place.

The terms of the 1601 Act emphasise the civil administrative aspects of poor law. In brief, each parish is responsible for raising a poor rate from each resident householder (it is eventually established that this will be based upon the value of the property they occupy) according to local financial need. This rate is set annually taking into account any money in hand and any parish debt outstanding from the previous year's expenses; it is demand-led and uncapped. Parish lands, charities and any other parish income are factored into this total, which is to be presented to and ratified annually by the Justices at Sessions. To sum up, each householder in a parish or township has a legal obligation to contribute to the poor rate and failure to pay leads to the seizure of goods and imprisonment until full payment is made; as for its modern descendant, the Local Council Tax. Finally, this structure of poor relief administered by local vestries composed of ratepayers, funded by a local rate and supervised by Justices, now constitutes a poor law system operating under the common law. Admittedly this "system" is not initially fully operational, nor in any way resembles modern centrally supervised welfare bureaucracies. Nevertheless, it constitutes all the necessary legal and administrative elements that will underpin and provide legal authority for poor relief for the next three hundred and fifty years.

The book details the prior legal existence of the settlement entitlement and those new terms contained in the 1662 Act. These confirm that the settled poor of any place are entitled to a share of the poor rate and add details of how settlement is acquired. The residence qualification set out in the terms of early post-Reformation statutes is shortened to "40 days at the least." This Act formalises the legal status of possessing a settlement, and is so understood in all subsequent case law. Settlement is now established as a legal right possessed by a settled individual who has an enforceable legal claim to a share of the poor rate when destitute. In addition, the Act is concerned with the removal of those poor not possessing a settlement in the 
place where they live. This removal is achieved by the Order of any two Justices of the Peace upon a complaint made by the overseers of the poor or churchwardens of any parish within 40 days of the poor person arriving in their parish. However, the Removal Order can only be made to a specific named parish where the Justices are satisfied, from legal proofs, the pauper possesses a settlement. There was a right of appeal by that named parish to Quarter Sessions, only on the grounds that the poor person did not possess a settlement in their parish or for procedural errors. These appeals could continue, and often did to the highest level; over time creating many thousands of settlement cases in the Law Reports, (noting that aside from rating matters a differentiated legal subject, poor law precedents are concerned with settlement issues). In short, under the terms and legal authority of the 1662 Act, a formal legal process evolved for asking and answering the settlement questions. This was based upon that fundamental legal presumption, that every person born in England and Wales possesses a settlement somewhere.

To summarise, in its earliest form settlement as a common law right was acquired simply through birth or residence. However, gaining and proving a legal settlement became an increasingly technical matter. This law continued to evolve from those terms both introduced and "understood" in the 1662 Act, via further amending statutes and developing case law, to become extremely complex and a major source of contemporary lawyers' incomes. The proportion and volume of income generated by settlement issues was equivalent to that earned from British criminal law practice today. Chapter 6 provides a settlement "case study" to illustrate some aspects of that doctrinal law.

Settlement law thus protects and delineates legal status and an individual could only be settled in one specific geographical place. The acquisition of settled status elsewhere automatically destroyed the previous settlement and the responsibility for maintaining that person then lay with the new settlement parish. Any person could exchange their place of settlement for another via the qualifying rules for each head of settlement. A woman acquires her husband's settlement upon marriage, a family's settlement always follows the father's settlement and thus they were removed as a unit by one legal action, although it became a requirement that the name and age of each member so removed should appear upon the face of the Order. Individuals who had qualifying status acquired a settlement wherever they resided. Anyone, including the "better sort" could be removed by legal process if they became destitute and had not acquired a settlement in the removing parish.

In order to access aid a poor person would approach a parish official, usually but not exclusively the overseer, to request aid; noting that "pauper" was a legal term for a person actually in receipt of poor relief. The first legal requirement was to demonstrate that they were destitute, and satisfying this requirement lay within the subjective judgement of individual parish officials. However, if the poor person possessed a settlement in the parish, no matter what the official decided, that parish had a legal obligation to relieve the poor person when destitute. Therefore, if relief is refused the Justices may make an Order to compel payment if they conclude that parish officers have improperly refused. Such an Order could be obtained by a poor person upon personal application to the Justices, thus allowing the individual further opportunity to demonstrate their destitution. This is not an appeals procedure; on the contrary it represents a long-standing personal right that was eventually given a procedural formality in the terms of an Act of 1714. Parish officials are now bound to assist the pauper and obey the magistrate's Order, failure to do so is contempt of court and the overseer incurs a personal liability.

The legal authority of the Acts of 1601 and 1662 remained in place after the reforms implemented under the terms of the Poor Law Amendment Act 1834. Chapters 2 and 9 of the book examine contemporary theories that influenced the form these took and those aspects of reform that directly impinged upon the legal rights of the poor. For the poor themselves, the terms of the 1834 Act had one major effect; that is the manner in which the relief to which they were still entitled would be provided. The draconian sections of the Act declared that the able bodied poor could only be relieved in a workhouse in regimented prison-like conditions. This was accompanied by the abolition of a poor person's right to seek an Order from a Justice for relief payments; in future Justices may only order relief in kind, and that solely in an emergency (s 54). This section did not abolish the right to relief for the settled poor, as that constitutes the legal foundations of, and explanation for, poor relief provision. Furthermore, the continuing legal authority of the 1601 Act permitted many parishes (and poor law unions) to exercise their legal discretion and pay out-relief to the poor (chapter 3). However, if relief must be given, as indeed it must but now in the workhouse, then this new poor law system was intended to control that relief, to begin to move control away from the localities and introduce discipline and efficiency by grafting elements of bureaucratic protomodernism onto a quasi-medieval survival.

It is difficult to imagine how great a loss these reforms represented for the poor; however there is sufficient evidence of poor law protest and resistance to show how bitterly this loss of legal rights was resented, a matter reconstructed within the book (chapter 9). Those reforms ensured that destitution increasingly became a route into the new union workhouses for many.

\section{CONCLUSION}

It is patent that the workhouse and the [new] poor law have become a part of Britain's "heritage" to the extent that the National Trust have restored Southwell Poor Law Union, Nottinghamshire for public enjoyment. 
Underpinning that heritage, bringing a frisson of vicarious empathy to Southwell's paying visitors, lies the social stigma and fear surrounding the new poor law, creating a cultural norm that survives and continues to influence aspects of modern welfare provision. It is that norm which influenced a desire for reform leading to the Beveridge Report of 1942. This in turn produced the modern welfare state, but modern welfare is disconnected from those original poor law personal rights, duties and obligations protected and enforced under the law of settlement and removal. There was and is no revival of the personal right to relief once possessed by the settled poor. This is unsurprising, for that right has been consistently undervalued, marginalised, denied and forgotten.

Reconstructing poor law's legal past illuminates the existence of that earlier culture of legal rights, their nature and their value to the poor. This is not to minimise the subjective elements in the amounts and manner poor relief was given, nor to deny that proving destitution allowed discretion to parish officials; elements today understood as "conditionality" (chapter 8). This antinomy operates to conceal those positive elements embedded within an entire legal structure with enforcement and sanctions to protect the right to relief. In this context the book proposes (chapter 8) that both government and local responses in Ireland during the Great Famine of the 1840s illustrate how little relief might have been given to the poor in England and Wales without those legal rights protected by the settlement entitlement. Irish poor law was implemented under the terms of the Poor Relief (Ireland) Act 1838 , which introduced a financially capped scheme and specifically excluded the right to relief.

In summary, Welfare's Forgotten Past concludes that historians have fallen into legal error in their consensus that there was no legal right to relief; an orthodoxy of denial arrived at by consulting each other and not the law and legal rules. The book retraces the route by which historians arrived at their legally incorrect conclusions and reconstructs a socio-legal alternate version of poor law history; one that demonstrates the doctrinal existence of the right to relief and provides a technical legal opinion to that effect, supported by the relevant legal authorities (chapter 3). This is accompanied by historical reconstructions of various aspects of poor law now factoring in that legal right to relief (chapters 5 and 7). Finally, the book concludes that there are three locations where that right is consistently in evidence; the first is within legal texts and the case law, rarely consulted and consistently mis-cited. The second is within those local vestry records that reveal centuries of uncontested unquestioned relief payments for the destitute settled poor; their significance has been consistently marginalised, misconstrued or undervalued in historical reconstructions. The third and final location is within the words and actions of the poor in support of their [legal] rights; fully attested and reconstructed within numerous poor law histories.
Unfortunately, because those historians have taken a position of denial, the poor have not been understood.

As such, for the discipline of history and for welfare law scholars who rely on works produced from within that discipline, this work is a revisionist text; in particular as it proposes that social histories of the poor law have compounded error by failing to provide legally accurate accounts of that past. It follows, that those who remain in denial concerning the legal nature of the right to relief, including historians, lawyers and policy-makers, necessarily focus on the relief of poverty as a gift of the state; recording a past where the poor exist to be judged, "improved" or watched constantly for fraud. This negativity, co-existing with a system of welfare provision based originally upon a legal obligation to relieve the poor, produced and continues to produce an operative tension, a fundamental antinomy. Welfare's current incarnation continues elements of that 400 year old legal responsibility to aid the poor having also absorbed elements of the post-1834 bureaucratic negative cultural norm that mistrusts the poor.

This current state of affairs is also problematic for North American welfare, where a version of the English poor law system was transplanted into the new colonial British settlements. "Forgetting" continues as welfare studies published within Britain and the USA specifically reconstruct poor law origins to authenticate welfare scholarship, but rely upon those accounts that persistently and inaccurately deny the existence of the legal right to relief. In consequence, as much as historical reconstructions enrich our understanding of how law is experienced in the past, it is still a requirement that we as lawyers test legal conclusions, or conclusions concerning law, with legal techniques. Such is the contribution law may bring to broader scholarship. This is not simply a matter of interdisciplinary angst for, as this book argues, "forgetting" the existence and importance of the legal right to relief continues to deform understanding of the development of the British and American welfare systems. The point is not just that we carry that past with us, but that for the relief of poverty, that past is being reconstructed and subsequently mined for answers and solutions to current political and legal problems surrounding poverty and welfare. This writer suggests we listen to those poor who spoke of rights and meant law; we owe it to their current successors in poverty.

- Welfare's Forgotten Past. A Socio-Legal History of the Poor Law, is a GlassHouse book, published by Routledge in 2010. The author wishes to thank the IALS, the London Legal History Society, and the Centre for Contemporary British History for their support.

Dr Lorie Charlesworth

Reader in Law and History, the Law School, Liverpool John Moores University 